\title{
CLIENT COMPANIES' PERCEPTION TOWARDS CREDIT RISK OF PRIVATE SECTOR BANKS WITH REFERENCE TO ICICI, HDFC, AXIS BANK, IDBI, AND YES BANK
}

\author{
Sunitha, G \\ PhD Research Scholar \\ Department of Business Management \\ KLEF (Deemed to be University), India \\ E-mail: sunitha27.g@gmail.com \\ https://orcid.org/0000-0002-7742-8924 \\ Dr. Venu Madhav, V \\ Associate Professor \\ Department of Business Management \\ KLEF (Deemed to be University), India \\ E-mail: dr.v.v.madhav@gmail.com \\ https://orcid.org/0000-0002-0089-5137
}

Received: October 14, $2021 \quad$ Accepted: November 16, $2021 \quad$ Online Published: January 15, 2022

DOI: $10.46281 /$ ijfb.v9i1.1545

URL: https://doi.org/10.46281/ijfb.v9i1.1545

\begin{abstract}
The banking sector at present is facing many issues; one among them is credit risk. A Credit risk is termed as an estimate or forecast of the default of a borrower failing to recover his interest amount or borrowed amount. Currently, the banker or the lender is at risk of recovering the interest amount and principal amount, increasing their recovery costs. The present study makes an attempt to know the awareness of customers towards credit risk of private sector banks. The research objective is to analyze the significant association between Client Company's perceptions with a view to credit risk. The study explains the major variation between client company's perspectives towards Indian private sector. The study explains about the impact of credit risk on banks profitability. The present study helps banks to prevail over the problem of credit risk. The study analysis the objectives of research, hypothesis formulated, research methodology, findings and conclusions are discussed. The secondary sources for the study are through the websites of banks, Journals and client company's websites. Primary data has been gathered from 285 client companies using convenience random sampling technique from private sector banks.
\end{abstract}

Keywords: Private Sector Banks, Credit Risk, Customers Perception, Profitability.

JEL Classification Codes: H32, Z33, E32, D21, C12, G21.

\section{INTRODUCTION}

Credit risk is measured as a major problem in banking sector. The factors responsible for credit risk may be financial factors, Business related factors, Government intervention and Policies of the banks etc. To decrease the non-performing assets we need to plan in advance on issuing of requested amount to the 
clients. Before issuing the loans to the customers, banks necessitate to analyze the financial background and their credit worthiness. This may help in identifying the borrowers who will settle up the borrowed sum and who defaults it.

\section{REVIEW OF LITERATURE}

Zergaw (2019) Author analyzed the elements that are upsetting the credit risk management practices in few Ethiopian private banks. Author evaluated the result of credit measurement, observing process and the effects of market risk, operational risk, and legal risk in credit risk management procedures of banks. The study examines the effect of creating Credit risk environments on credit risk management in accomplishment of the Banks and to evaluate credit granting procedures of the banks and its outcome on credit risk management of the banks. Yüksel et al. (2018) Authors in the present study made an effort to analyze the elements which manipulate credit risk in Azerbaijani banks. They suggested the banks to verify the ratings on customers before granting loans to them. Considering 10 banks, the analysis was done considering their asset size with 10 variables. Panel logic methodology was used for the study and analyzed that 4 independent variables like capital adequacy ratio, joblessness rate and interest rate affect credit risk of Azerbaijani banks. Zheng et al. (2018) the study tried to show the backward effect of credit defaults in bank profitability though other factors are considered with equal importance. The study chronologically showed the uni-variate to multivariate regression to determine the best executed model. The study addressed the credit risk which is the prevailing question in the contemporary time horizon. Sandada and Kanhukamwe (2016) explained the crucial elements that are affecting the credit risk of Zimbabwe banking sector. The study ascertained the impact of macro-economic, industry and bank related factors on increasing credit risk. The bank specific factors highlight the need for banking institution to take staff training on various aspects of banking operations seriously. The research findings provide a platform for further research on how to deal with the credit risk problems.

The research gap identified is that there are very less studies which showed an influence of Client Company's perception towards credit risk. No study was carried out on analyzing the significant association of Client Company's perception towards credit risk. The current study recovered the research gap. The current study makes an attempt to minimize the consequences of credit risk on banks profitability and suggests suitable methods to overcome credit with more samples.

After studying various research papers and articles, besides the above mentioned, the following significant remarks with regard to the study were made.

\section{OBJECTIVES OF THE STUDY}

- To analyze the significant influence of client companies perception towards credit risk.

- To evaluate the significant association of client companies perception towards credit risk.

- To study the impact of credit risk on banks profitability.

- To suggest suitable methods to overcome credit risk.

\section{SCOPE OF THE STUDY}

The scope is limited to analyzing the customer's perception towards credit risk of private sector banks. Primary data has been gathered from 285 client companies.

\section{STATEMENT OF THE PROBLEM}

Credit risk is the reason for economic decline as banks fail because of default risk from client companies, which has had a negative impact on the economic development of many nations around the world.

\section{Research Design}

\section{RESEARCH METHODOLOGY}

The study uses descriptive research design with a survey method by convenience random sampling technique to assemble the facts. The analysis was conducted to analyze the client company's perception 
towards credit risk for the solutions like Credit risk management, Fraud management, and better loan securitization etc.

\section{Sample Size}

The present study collected samples from 285 client companies of private sector banks using convenience random sampling technique. Questionnaire was forwarded to 1880 companies all over the country. But the responses were received from 285 companies.

\section{Statistical Tools}

Few statistical tools like percentage analysis, ANOVA, Chi-Square test and Regression were used to examine the collected data to evaluate the customer's perception towards credit risk using SPSS.

\section{HYPOTHESIS OF THE STUDY}

- There is no significant influence of customer's perception towards credit risk.

- There is no significant association of customer's perception towards credit risk.

- There is no significant impact of credit risk on banks profitability.

RESULTS AND DISCUSSIONS

Table 1. Tabular representation of Demographic factor of the client companies

\begin{tabular}{|c|c|c|}
\hline Type of Business & Number & Percentage \\
\hline Agricultural based & 23 & 8 \\
\hline Manufacturing & 56 & 20 \\
\hline Construction & 38 & 13 \\
\hline Health care & 44 & 15 \\
\hline Education & 26 & 10 \\
\hline Petroleum & 32 & 11 \\
\hline Others & 66 & 23 \\
\hline Total & 285 & 100 \\
\hline Annual Turnover & Number & Percentage \\
\hline Below 100 crores & 18 & 6 \\
\hline 101 crores to 200 crores & 5 & 2 \\
\hline 201 crores to 300 crores & 58 & 20 \\
\hline 301 crores to 400 crores & 70 & 25 \\
\hline 401 crores to 500 crores & 55 & 19 \\
\hline 501 crores and above & 33 & 12 \\
\hline Others & 46 & 16 \\
\hline Total & 285 & 100 \\
\hline Place of the organization & Number & Percentage \\
\hline Andhra Pradesh & 35 & 12 \\
\hline Arunachal Pradesh & 15 & 5 \\
\hline Assam & 6 & 2 \\
\hline Bihar & 11 & 4 \\
\hline Madhya Pradesh & 19 & 7 \\
\hline Uttar Pradesh & 9 & 3 \\
\hline Gujarat & 9 & 3 \\
\hline Goa & 14 & 5 \\
\hline Kerala & 15 & 5 \\
\hline
\end{tabular}




\begin{tabular}{|c|c|c|}
\hline Karnataka & 18 & 6 \\
\hline Meghalaya & 15 & 5 \\
\hline Odisha & 11 & 4 \\
\hline Mizoram & 9 & 3 \\
\hline Nagaland & 11 & 4 \\
\hline Maharashtra & 15 & 5 \\
\hline Himachal Pradesh & 16 & 6 \\
\hline Tripura & 14 & 5 \\
\hline Rajasthan & 20 & 7 \\
\hline Uttarakhand & 10 & 4 \\
\hline Telangana & 13 & 5 \\
\hline Total & 285 & 100 \\
\hline Bank & Number & Percentage \\
\hline ICICI & 57 & 20 \\
\hline HDFC & 53 & 18 \\
\hline Axis bank & 57 & 20 \\
\hline IDBI & 59 & 21 \\
\hline Yes bank & 59 & 21 \\
\hline Total & 285 & 100 \\
\hline
\end{tabular}

Source: Authors own work

The data was gathered from 285 client companies, the details of the companies are explained here. Considering the type of business other business are $23 \%$, manufacturing companies are $20 \%$ and Health care are $15 \%$. Other type of businesses like Construction, Education and Petroleum contributed fewer shares. The companies having an annual turnover of 301 crores- 400 crores are $25 \%, 201$ crores300 crores are $20 \%$ and 401 crores- 500 crores are $19 \%$.

Questionnaire was forwarded to few companies from all the states. The questionnaire was forwarded to 1880 companies all over the country. But the responses received are 285, out of which the responses from Andhra Pradesh are 12\%, Madhya Pradesh is 7\% and Rajasthan are 7\%. The responses from other states are very less. The banks opted by the client companies are IDBI and Yes bank are $21 \%$, ICICI and Axis bank are $20 \%$ and HDFC are $18 \%$.

Table 2. Tabular representation of influence of customer perception towards credit risk

\section{Test of Homogeneity of Variances}

\section{Credit Risk}

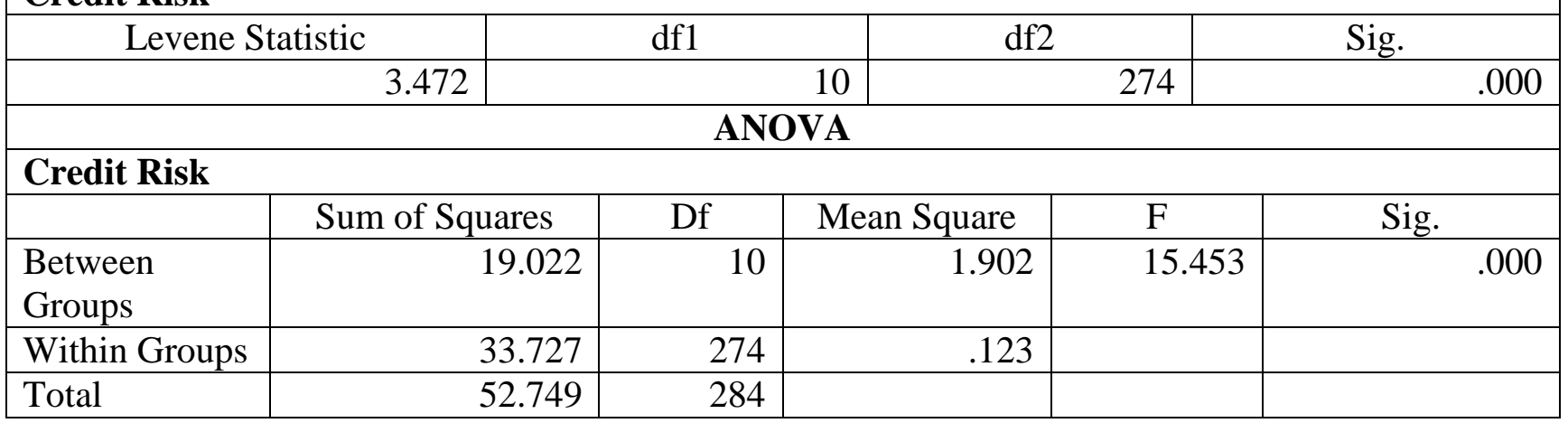

Source: Authors own work 
ANOVA is a test of hypothesis that is suitable to compare means of a permanent variable in two or more independent comparison groups. Here, Customer perception has been altered in relation to Credit risk. Since the $\mathrm{p}$ values are 0.010 that are commenced to be less than 0.05 , the null hypothesis is discarded and alternative hypothesis is established at 5\% level of significance, therefore the strength of association between variables is very strong. There is a significance difference on the Customer perception towards Credit risk.

Table 3. Tabular representation of significant association of consumer's perception towards credit risk

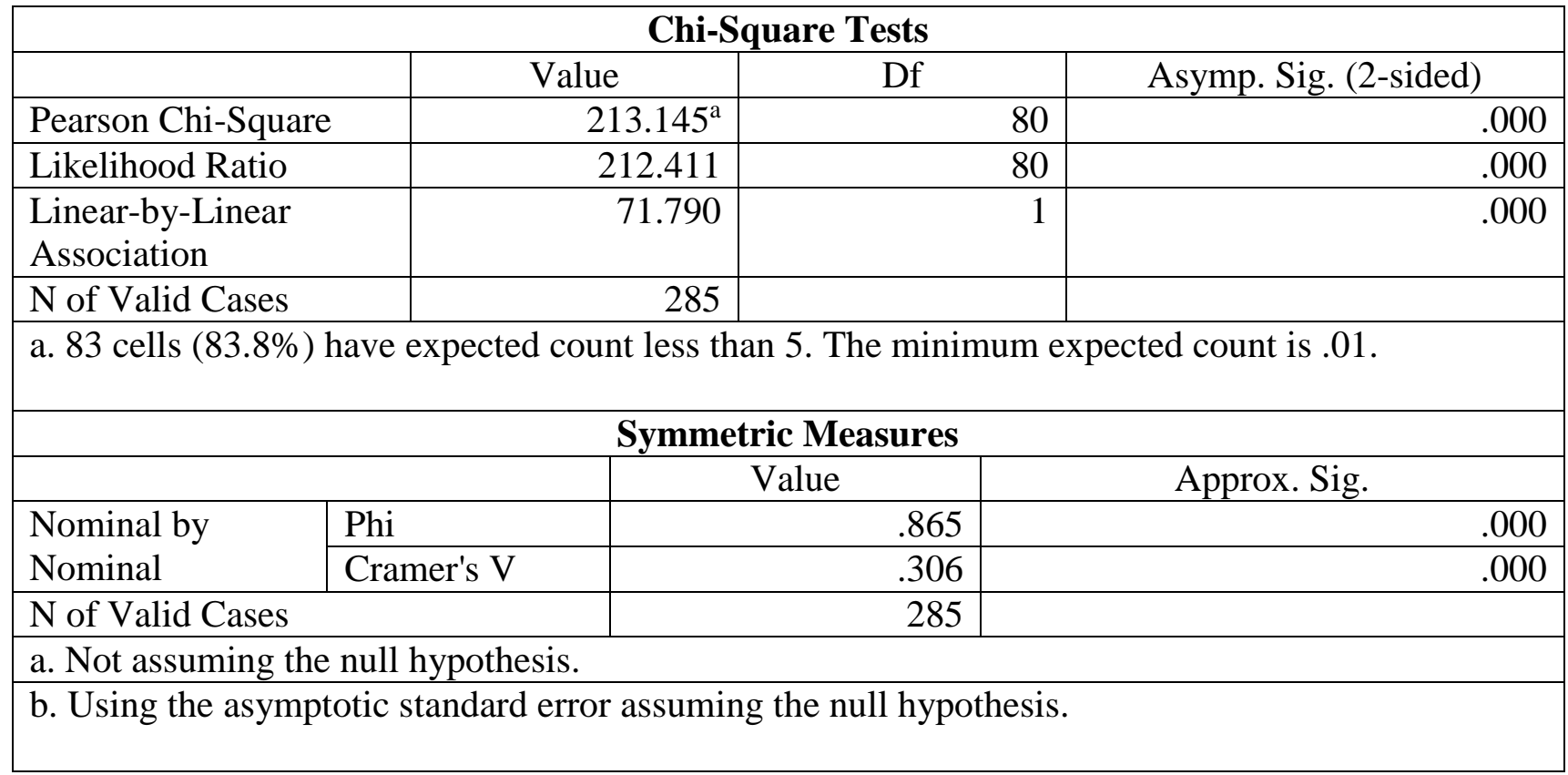

\section{Source: Authors own work}

Chi-Square is a single value that explains about how much difference exists between the observed counts and the expected count. For testing Chi-square, a p-value that is smaller than or equal to the significance level explains that there is satisfactory facts to terminate that the new distribution is not the same as the conventional distribution. Therefore we can conclude that a relationship exists between the variables. A low value for chi-square means there is a high correlation between two sets of data. Since the p values are 0.000 which are less than 0.05 . The null hypothesis is rejected and alternative hypothesis is accepted at 5\% level of significance, therefore the strength of association between variables is very strong. There is a significance association of Consumer perception towards Credit risk.

Table 4. Tabular representation of significant impact of credit risk on banks profitability

\begin{tabular}{|c|c|c|c|c|c|c|c|c|c|}
\hline \multicolumn{10}{|c|}{ Model Summary } \\
\hline \multirow[t]{2}{*}{ Model } & \multirow[t]{2}{*}{$\mathrm{R}$} & \multirow{2}{*}{$\begin{array}{c}\mathrm{R} \\
\text { Square }\end{array}$} & \multirow{2}{*}{$\begin{array}{l}\text { Adjusted } \\
\text { R Square }\end{array}$} & \multirow{2}{*}{$\begin{array}{l}\text { Std. Error } \\
\text { of the } \\
\text { Estimate }\end{array}$} & \multicolumn{5}{|c|}{ Change Statistics } \\
\hline & & & & & $\begin{array}{c}\text { R Square } \\
\text { Change }\end{array}$ & $\begin{array}{c}\mathrm{F} \\
\text { Chang }\end{array}$ & df1 & df2 & $\begin{array}{c}\text { Sig. F } \\
\text { Change }\end{array}$ \\
\hline 1 & $.568^{\mathrm{a}}$ & .323 & .321 & .31953 & .323 & 135.13 & 1 & 283 & .000 \\
\hline \multicolumn{10}{|c|}{ a. Predictors: (Constant), Credit Risk } \\
\hline \multicolumn{10}{|c|}{ ANOVAa $^{a}$} \\
\hline \multicolumn{3}{|l|}{ Model } & $\begin{array}{c}\text { Sum of } \\
\text { Squares }\end{array}$ & Df & \multicolumn{2}{|c|}{ Mean Square } & $\mathrm{F}$ & \multicolumn{2}{|r|}{ Sig. } \\
\hline \multirow[t]{2}{*}{1} & \multicolumn{2}{|c|}{ Regression } & 13.797 & 1 & \multicolumn{2}{|c|}{13.797} & 135.130 & & \multirow[t]{2}{*}{$.000^{\mathrm{b}}$} \\
\hline & \multicolumn{2}{|c|}{ Residual } & 28.894 & 283 & \multicolumn{2}{|r|}{.102} & & & \\
\hline
\end{tabular}




\begin{tabular}{|c|c|c|c|c|c|c|}
\hline & Total & 42.69 & 284 & & & \\
\hline \multicolumn{7}{|c|}{ a. Dependent Variable: Banks profitability } \\
\hline \multicolumn{7}{|c|}{ b. Predictors: (Constant), Credit Risk } \\
\hline \multicolumn{7}{|c|}{ Coefficients $^{\mathrm{a}}$} \\
\hline \multirow{2}{*}{\multicolumn{2}{|c|}{ Model }} & \multicolumn{2}{|c|}{$\begin{array}{c}\text { Unstandardized } \\
\text { Coefficients }\end{array}$} & $\begin{array}{c}\text { Standardized } \\
\text { Coefficients }\end{array}$ & \multirow[t]{2}{*}{$\mathrm{t}$} & \multirow[t]{2}{*}{ Sig. } \\
\hline & & $\mathrm{B}$ & Std. Error & Beta & & \\
\hline \multirow[t]{2}{*}{1} & (Constant) & 1.909 & .191 & & 9.990 & .000 \\
\hline & $\begin{array}{l}\text { Credit } \\
\text { Risk }\end{array}$ & .511 & .044 & .568 & 11.625 & .000 \\
\hline
\end{tabular}

Regression is a reliable method of identifying which variables have impact on a particular topic. The process of performing a regression allows you to confidently determine which factors matter most, which factors can be ignored, and how these factors influence each other. R-squared $\left(\mathrm{R}^{2}\right)$ is a statistical measure that elaborates the ratio of the variation for a dependent variable that's explained by an independent variable or variables in a regression model. The p-value is tested for all the terms, and results illustrates that the null hypothesis that the coefficient is equal to zero (no effect). A low p-value ( $<$ 0.05 ) illustrates that you can reject the null hypothesis. Typically, you use the coefficient $p$-values to determine which terms to keep in the regression model.

As the R-Square value should be between 0 and 1 , here it is 0.323 and the $\mathrm{p}$ value is 0.000 which is less than 0.05 , therefore null hypothesis is rejected and alternate hypothesis is accepted. Therefore changes in Credit risk are associated with Bank profitability.

\section{FINDINGS}

- Demographic factors explains that other type of businesses are more than the businesses like Manufacturing, Health care, Construction and Petroleum.

- The annual turnover of majority of the Client companies is 301-400 crores, which is a good indication of growth of income of the organizations.

- People from Andhra Pradesh have responded more to the questionnaire when compared to other states.

- The percentage of banks selected by the respondents is nearly equal. Maximum percent of the respondents have opted to all the selected banks.

- There is a significant influence of Client Company's perception towards credit risk. This represents that Client companies have comprehensive particulars on the basis for the increase of credit risk like Customers default, Banks internal rating, inappropriate credit policies and Volatile interest rates.

- There is a significant association of Client Company's perception towards credit risk. Here, the factors like Consumers failure to repay the loan amount, inappropriate rating from rating agencies and Banks internal rating are considered to evaluate the Client Company's perception towards credit risk.

- There is an impact of credit risk on banks profitability. The factors like Bank size, Capital ratio, Deposits ratio, Liquidity ratios are considered to analyze the impact of credit risk on Bank profitability.

- To improve banks internal rating.

\section{SUGGESTIONS}

- Inspection from banks is to be done accordingly.

- To advise the customers or the businesses who took loan when needed. 
- To provide proper rating from credit rating agencies.

- Banks should limit the borrowing amount, as the high the borrowed sum higher would be the credit risk.

- Banks have to evaluate the financial arrangement of the firm thoroughly before granting loan to them.

\section{CONCLUSION}

Credit risk of private sector banks can be slowly but surely decreased by following few suggestions mentioned in this paper resembling improving internal rating from banks and external rating from credit rating agencies. Banks can advise and provide training to the customers when needed. It assists the client companies to sustain in his business environment. As these recommendations are constructed on the perception of Client companies, there may be probably other factors which are responsible for increase of credit risk. Banks have to take precautionary measures to overcome these issues. When banks credit risk is decreased, the profitability of the banks increases.

Conceptualization: V. Venu Madhav

\section{AUTHOR CONTRIBUTIONS}

Data Curation: Sunitha, $\mathrm{G}$

Formal Analysis: Sunitha, G

Funding Acquisition: Sunitha, G

Investigation: Sunitha, G

Methodology: Sunitha, G

Project Administration: V. Venu Madhav

Resources: Sunitha, G

Software: Sunitha, G

Supervision: V. Venu Madhav

Validation: Sunitha, G, V. Venu Madhav

Visualization: Sunitha, G

Writing - Original Draft: Sunitha, G

Writing - Review \& Editing: Sunitha, G, V. Venu Madhav

\section{CONFLICT OF INTEREST STATEMENT}

The author declare that they have no competing interests.

\section{ACKNOWLEDGEMENT}

All authors contributed equally to the conception and design of the study.

\section{REFERENCES}

Sandada, M., \& Kanhukamwe, A. (2016). An analysis of the factors leading to rising credit risk in the Zimbabwe banking sector, 12(1), 80-94

Yüksel, S., Mukhtarov, S., Mammadov, E., \& Özsarı, M. (2018). Determinants of profitability in the banking sector: an analysis of post-soviet countries. Economies, 6(3), 41. https://doi.org/10.3390/economies6030041

Zergaw, F. (2019). Factors affecting credit risk management practices, the case of selected private commercial banks in Ethiopia, International journal of advanced research, 7(1), 811-849. http://dx.doi.org/10.21474/IJAR01/8392

Zheng, C., Sarker, N., \& Nahar, S. (2018). Factors affecting bank credit risk: An empirical insight. Journal of Applied Finance and Banking, 8(2), 45-67. 
1. Name of the company:

\section{APPENDICES}

2. Type of business

1. Agricultural based [ ]

2. Manufacturing [ ]

3. Construction [ ]

4. Health care [ ]

5. Education [ ]

6. Petroleum [ ]

7. Others [ ]

\section{Annual Turnover:}

1. Below 100 crores

2. 101 crores to 200 crores

3. 201 crores to 300 crores

4. 301 crores to 400 crores

5. 401 crores to 500 crores

6. 501 crores and above

4. What is your place of organization

- list of states[ ]

\section{Name of the bank where you have your account}

1. ICICI [ ]

2. HDFC [ ]

3. Axis bank [ ]

4. IDBI [ ]

5. Yes bank [ ]

6. Credit risk

\begin{tabular}{|l|l|l|l|l|l|}
\hline & SD & Disagree & Neutral & Agree & SA \\
\hline Customer default & & & & & \\
\hline Banks internal rating & & & & & \\
\hline Inappropriate credit policies & & & & & \\
\hline volatile interest rates & & & & & \\
\hline
\end{tabular}

\section{Banks profitability}

\begin{tabular}{|l|l|l|l|l|l|}
\hline & SD & Disagree & Neutral & Agree & SA \\
\hline Bank size & & & & & \\
\hline Capital ratio & & & & & \\
\hline Deposits ratio & & & & & \\
\hline Liquidity ratio & & & & & \\
\hline
\end{tabular}

\section{Customers perception on Credit risk}

\begin{tabular}{|l|l|l|l|l|l|}
\hline & SD & Disagree & Neutral & Agree & SA \\
\hline Consumer's failure & & & & & \\
\hline Inability to repay & & & & & \\
\hline Banks internal rating & & & & & \\
\hline Inappropriate rating from rating agencies & & & & & \\
\hline
\end{tabular}


9. Suggestions to overcome credit risk

\begin{tabular}{|l|l|l|l|l|l|}
\hline & SD & Disagree & Neutral & Agree & SA \\
\hline Improve banks internal rating & & & & & \\
\hline Inspection from banks & & & & & \\
\hline Advise customers when needed & & & & & \\
\hline Proper ratings from rating agencies & & & & & \\
\hline
\end{tabular}

\section{Copyrights}

Copyright for this article is retained by the author(s), with first publication rights granted to the journal. This is an open-access article distributed under the terms and conditions of the Creative Commons Attribution license (https://creativecommons.org/licenses/by/4.0) 